
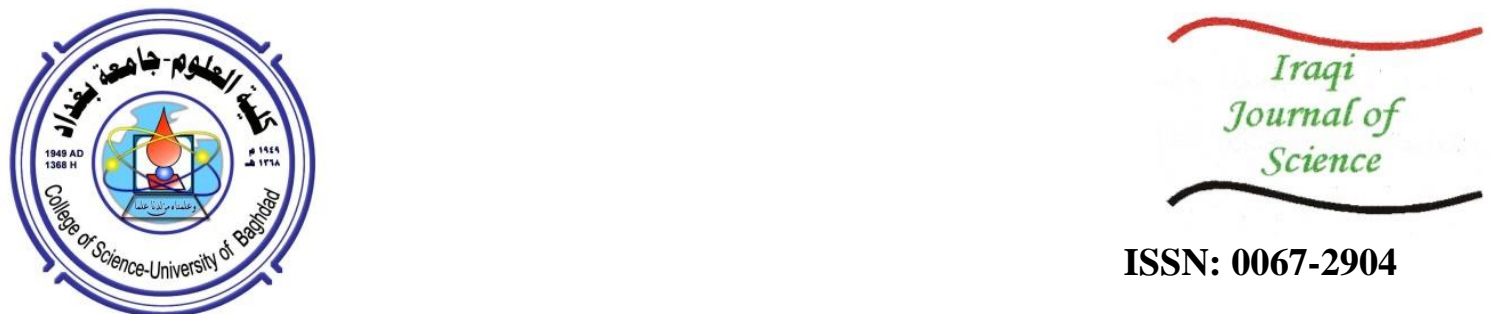

ISSN: 0067-2904

\title{
Preparation and Characterization of $\operatorname{In}_{2} \mathrm{O}_{3}-\mathrm{CuO}$ Nanocomposite Thin Films as $\mathrm{NH}_{3}$ Gas Sensor
}

\author{
Abd alhameed A. Hameed, Hamid S. AL-Jumaili* \\ Physics Department, College of Education for Pure Sciences, University of Anbar, Ramadi, Iraq .
}

Received: 4/10/2020

Accepted: 10/1/2021

\begin{abstract}
An $\mathrm{NH}_{3}$ gas sensor was prepared from nanocomposite films of indium oxidecopper oxide mixtures with ratios of 0,10 , and $20 \mathrm{Vol} \%$ of copper oxide. The films were deposited on a glass substrate using chemical spray pyrolysis method (CSP) at $400^{\circ} \mathrm{C}$. The structural properties were studied by using X-ray diffraction (XRD) and atomic force microscopy ( AFM). The structural results showed that the prepared thin films are polycrystalline, with nano grain size. By mixing copper oxide with indium oxide, the grain size of the prepared thin films was decreased and the surface roughness was increased. The UV-Visible spectrometer analysis showed that the prepared thin films have high transmittance. This transmittance was decreased by mixing copper oxide with indium oxide. The direct optical energy gap ranged $3.5-3 \mathrm{eV}$, which was decreased with increasing copper oxide concentration. The sensitivity of the prepared gas sensor was measured towards $\mathrm{NH}_{3}$ gas at a concentration of $71 \mathrm{ppm}$ with operating temperatures of 100,150,200, 250 and 30) ${ }^{\circ} \mathrm{C}$, according to the change of sensor resistance. This sensitivity of the mixture oxides showed a value of about nine times greater than that of individual indium oxide thin films. The results of the optimum gas sensor properties demonstrated a sensitivity value of $75.06 \%$, response time of $10 \mathrm{~s}$, and recovery time of $11 \mathrm{~s}$, at a mixing ratio of $20 \%$ of copper oxide and an operating temperature of $200^{\circ} \mathrm{C}$.
\end{abstract}

Keywords; Thin films, optical and structural properties, Nano - composite, $\operatorname{In}_{2} \mathrm{O}_{3}-$ $\mathrm{CuO}, \mathrm{NH}_{3}$ gas sensor.

NH NH $_{3}$ In $\mathrm{O}_{3}$-CuO

$$
\begin{aligned}
& \text { "عبدالحميد عبدالكريم حميد ، حامد صالح الجميلي" } \\
& \text { قسم الفيزياء، كلية التربية للعلوم الصرفة، جامعة الانبار ، الرمادي ، العراق } \\
& \text { الخلاصة } \\
& \text { تم في هذا البحث تصنيع متحس غاز NH3 من اغثية متراكب نانوي من خليط اوكسيد الانديوم-اوكسيد } \\
& \text { النحاس بنسب حجمية ( ) Vol\% ) من اوكسيد النحاس .الغشاء مرسب على قواعد زجاجية } \\
& \text { بأستخدام تقنية التحلل الكيميائي الحراري , بدرجة حرارة Co C } 400 \text {, الخصائص التركيبية درست باستخدام } \\
& \text { تقنية حيود الاشعة السينية (XRD) ومجهر القوة الذرية (AFM) ) ـ النتائج التركيبية بينت ان الاغشية الرقيقة }
\end{aligned}
$$

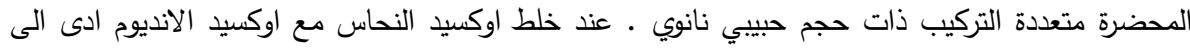

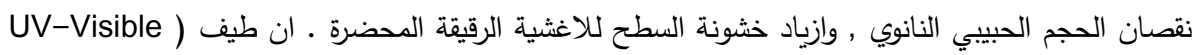

$$
\begin{aligned}
& \text { (spectrometer }
\end{aligned}
$$

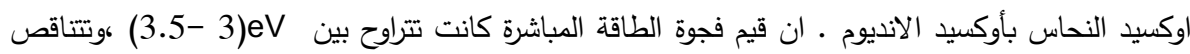

*Email: hameed.alamery1234@gmail.com 


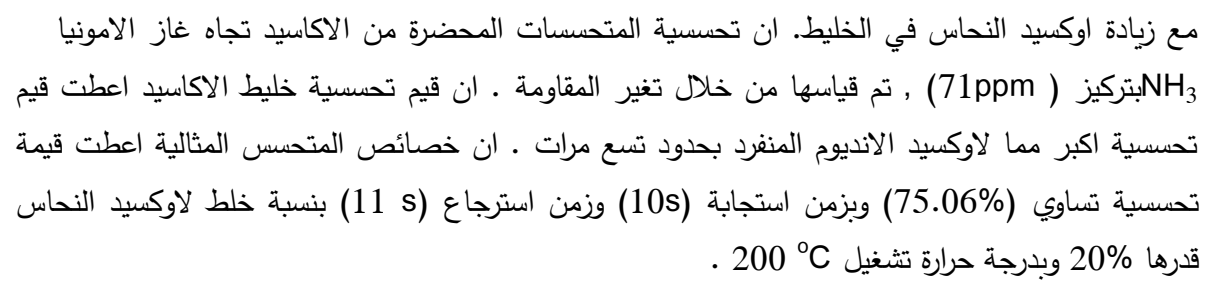

\section{Introduction}

Semiconductor metal oxide (SMO) has many advantages, such as low cost, easy for fabrication, low detection limits for gases, in addition to their long life, non-toxicity, and high conductivity. For these properties, it has been used in many different fields and applications, such as solar cells and gas sensors [1]. SMO has excellent sensitivity, rapid response, and long-term stability. Therefore, it has been widely used in the detection of dangerous and explosive gases in the environment $[2,3]$. The enhanced sensing properties of the thin film's composite can be attributed to the p-n heterojunction contact between the semiconductor metal oxides [4]. Moreover, many attempts have been made to enhance the sensitivity and selectivity of the transparent metal oxide sensors by modifying the surface through adding metallic impurities and mixing different metal oxides [4-9]. Indium oxide $\left(\operatorname{In}_{2} \mathrm{O}_{3}\right)$ is an n-type semiconductor with a wide energy gap n (3.5- $3.75 \mathrm{eV})$. Also, it has high conductivity, low resistance, and ability to modify its surface by doping or mixing with some metals [10]. $\mathrm{CuO}$ is a ptype semiconductor, with a narrow energy gap (1.2-1.9 eV), low cost, high catalytic activity, good electrochemical performance, and excellent response to most neutral and reducing gases [11-12]. CuO is studied as a p-type gas sensor material but not used widely as mixed oxide with n-type metal oxide semiconductors, such as $\mathrm{In}_{2} \mathrm{O}_{3}, \mathrm{SnO}_{2}$, and $\mathrm{ZnO}$ for gas sensor applications [13]. Ammonia gas $\left(\mathrm{NH}_{3}\right)$ is highly toxic, being commonly used in agriculture, food industry, and chemical industry. In addition, it is known to be exceptionally harmful to the human body and the environment. Thus, highly sensitive detection is necessary for its monitoring [14]. Sensitivity tests for the prepared films aim to create optimal conditions for the operation of the $\mathrm{NH}_{3}$ gas sensor [15]. The present study was designed to manufacture an $\mathrm{NH}_{3}$ sensor from nanocomposite thin films made of a mixture of indium oxide and copper oxide deposited on a glass substrate by a simple chemical spray pyrolysis technique. The structural, optical, and sensing properties of $71 \mathrm{ppm} \mathrm{NH}_{3}$ gas of the prepared films were studied.

\section{Experimental Details}

Nano thin films of indium oxide pristine and the mixture of thin films of indium oxide- copper oxide were deposited with different volumetric ratios of copper solution $(0,10,20 \mathrm{Vol} . \%)$, using the chemical spray pyrolysis technique. The materials' solutions were prepared from indium chloride $\left(\mathrm{InCl}_{3}\right)$ with a purity of $97 \%$ (supplied by $\mathrm{CDH}$ ) and copper chloride $\left(\mathrm{CuCl}_{2} \cdot 2 \mathrm{H}_{2} \mathrm{O}\right)$ with a purity of 98 $\%$ (BDH chemicals Ltd Poole, England). The molarity of solutions was $0.01 \mathrm{M}$. The slides were cleaned with detergent water and ethanol using an ultrasonic bath for 10 minutes. The solutions were sprayed automatically on a glass substrate at $400^{\circ} \mathrm{C}$ using comprised air of 1 bar as a gas carrier at a period time of spraying of $5 \mathrm{~s}$ and $(20 \mathrm{~s})$ wait alternately, with a deposition rate of $2.5 \mathrm{ml} / \mathrm{min}$. The optical method was used to determine the thickness of the prepared films, which ranged $250-320 \mathrm{~nm}$. The optical and structural properties were studied using UV-Visible spectrometer, XRD, and AFM. The sensitivity properties of the sensor toward NH3 gas were measured at a concentration of $71 \mathrm{ppm}$ and different operating temperatures.

\section{Results and discussion \\ 3.1 Structural properties}

Figure-1 shows the X-ray diffraction of the prepared films having a polycrystalline structure with nanocrystalline size. The single indium oxide films have several crystalline peaks of (211), (222), (400), (431), (440), (622) at the diffraction angles $2 \mathrm{q}=\left(21.43,30.51,35.37,45.5,50.92,60.56^{\circ}\right)$, respectively. The predominant peak is at (222) with a cubic structure, in accordance to the card (JCPDS 01-088-2160), which is in agreement with the results reported by Zhi-HongMaa et al. [10] and Wojtyła et al. [16]. The results also showed that, when adding 10 and $20 \%$ of copper oxide to indium oxide, the predominant peak shifts to the larger angles and the previously appeared peak (431) was missing. Also, there is no compound between the two oxides, which indicates the formation of the composite between the two oxides. The crystalline size was calculated using the Debye- Scherer equation. It was found that the addition of copper oxide leads to a decrease in the crystal size as 
compared with individual indium oxide thin film, as shown in Table-1.

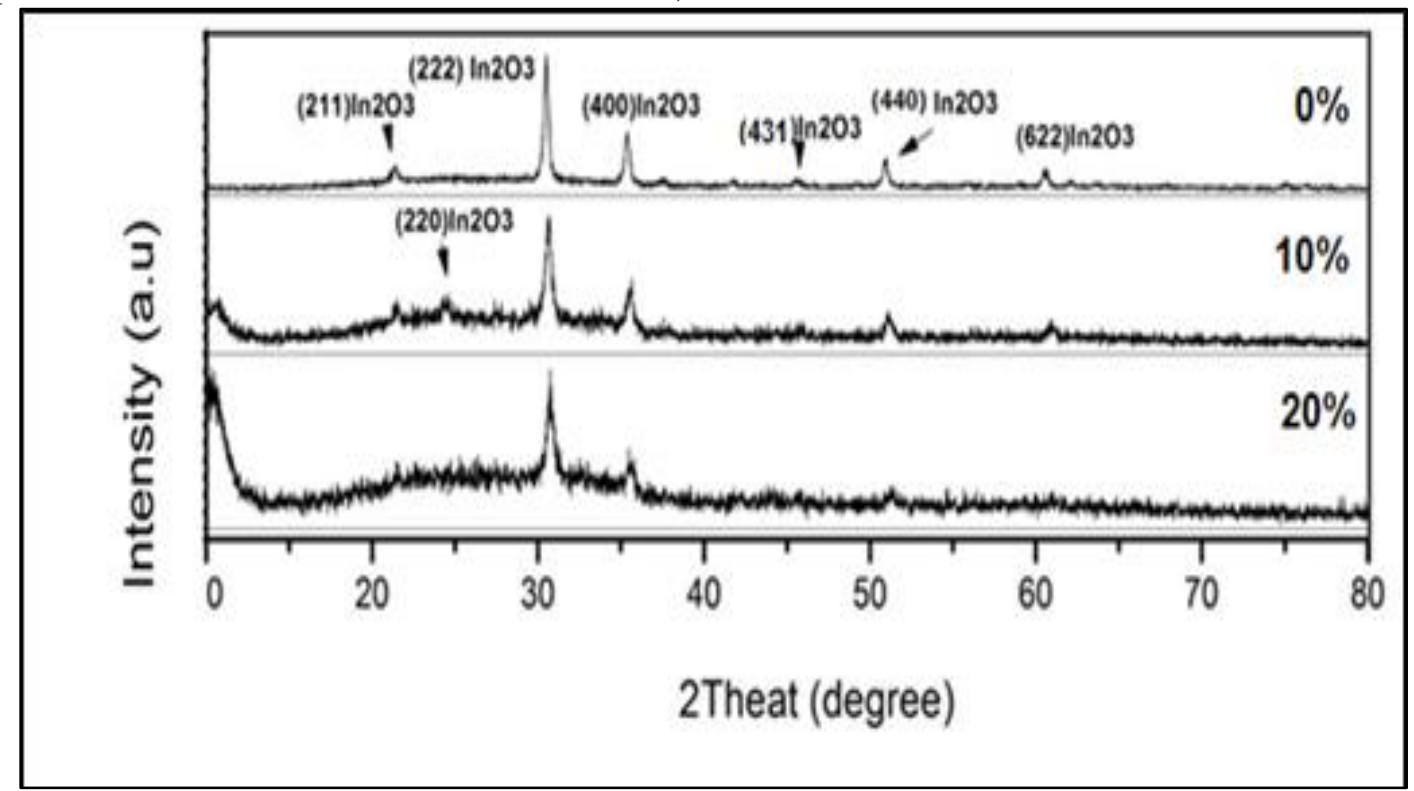

Figure 1- The X-ray diffraction of the prepared films

Figure-2 shows the atomic force microscopy (AFM) images of the prepared thin films. The results show that indium oxide has an average grain size of $107.5 \mathrm{~nm}$ and average roughness of $3.13 \mathrm{~nm}$. Adding 10 and $20 \%$ copper oxide to indium oxide leads to a decrease in the grain size to $82.25 \mathrm{~nm}$ and $45.27 \mathrm{~nm}$, respectively, along with an increases the roughness and the root mean square, as shown in Table-1. The shape of the grains changes from spherical and elliptical at $10 \%$ copper oxide to spherical at $20 \%$ copper oxide, due to the nanocomposite formation of the mixed films, as shown in figure 2. This behavior corresponds to the XRD result and an agreement with that described by Suhai et al. [5] and Sofi et al. [17].

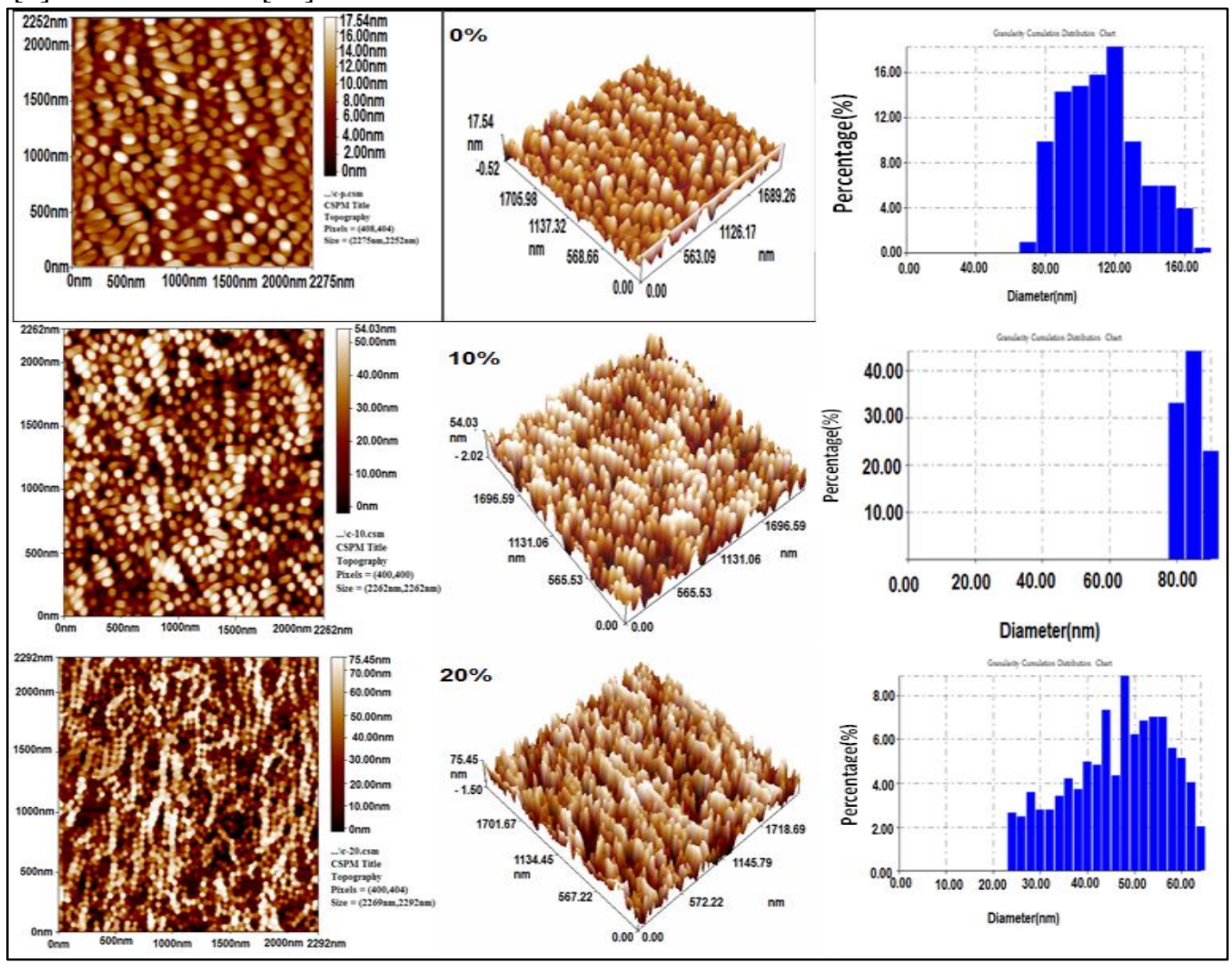

Figure 2-AFM images of the prepared films 
Table 1-The values of crystalline size, grain size, average roughness, and root mean square of the prepared films

\begin{tabular}{|c|c|c|c|c|c|}
\hline \multirow{3}{*}{ Sample content } & \multirow{3}{*}{ Oxide type } & XRD & \multirow{2}{*}{\multicolumn{3}{|c|}{ AFM }} \\
\hline & & $\begin{array}{c}\text { Crystal } \\
\text { size }\end{array}$ & & & \\
\hline & & $\begin{array}{c}\mathrm{D} \\
(\mathrm{nm})\end{array}$ & $\begin{array}{c}\text { Roughness } \\
\text { (nm) }\end{array}$ & $\begin{array}{l}\text { Root mean } \\
\text { square(nm) }\end{array}$ & $\begin{array}{c}\text { Grain } \\
\text { size }(n m)\end{array}$ \\
\hline $100 \% \mathrm{InCl}_{3}$ & $\mathrm{In}_{2} \mathrm{O}_{3}$ & 27.9 & 3.13 & 3.84 & 107.5 \\
\hline $90 \% \mathrm{InCl}_{3}+10 \% \mathrm{CuCl}_{2}$ & $\mathrm{In}_{2} \mathrm{O}_{3}+\mathrm{CuO}$ & 16.27 & 14.2 & 16.4 & 82.25 \\
\hline $80 \% \mathrm{InCl}_{3}+20 \% \mathrm{CuCl}_{2}$ & $\mathrm{In}_{2} \mathrm{O}_{3}+\mathrm{CuO}$ & 22.16 & 19.2 & 22.2 & 45.27 \\
\hline
\end{tabular}

\section{3-2. Optical properties}

Optical examinations of the prepared indium oxide-copper oxide mixture showed a high transmittance within the wavelengths of visible light, as shown in Figure-3. The transmittance of the prepared individual indium oxide films reached $74 \%$ at a wavelength of $650 \mathrm{~nm}$, as shown in Figure- 3 . The transmittance was decreased to $66 \%$ at $20 \%$ of copper solution and a wavelength of $650 \mathrm{~nm}$. The reason for the decrease in transmittance after adding copper oxide is the high absorption of copper oxide within the visible wavelengths, which corresponds to the small value of the optical energy gap. These results have good agreement with those of Mahdi et al. [5].

The direct optical energy gap of the prepared films was calculated from the relationship between the energy values of the photon $h v$ and $\alpha h v 2$, as shown in Figure-4. The value of the direct energy gap for $\operatorname{In}_{2} \mathrm{O}_{3}$ was equal to $3.5 \mathrm{eV}$. Then, it was decreased with increasing copper oxide concentration to $3.3 \mathrm{eV}$ ) for $10 \%$, and to $3 \mathrm{eV}$ for $20 \%$. The decrease in the direct energy gap value of the mixture $\mathrm{In}_{2} \mathrm{O}_{3}$-CuO films together with the increase in the ratio of copper oxide concentration occurred due to the small energy gap value of copper oxide.

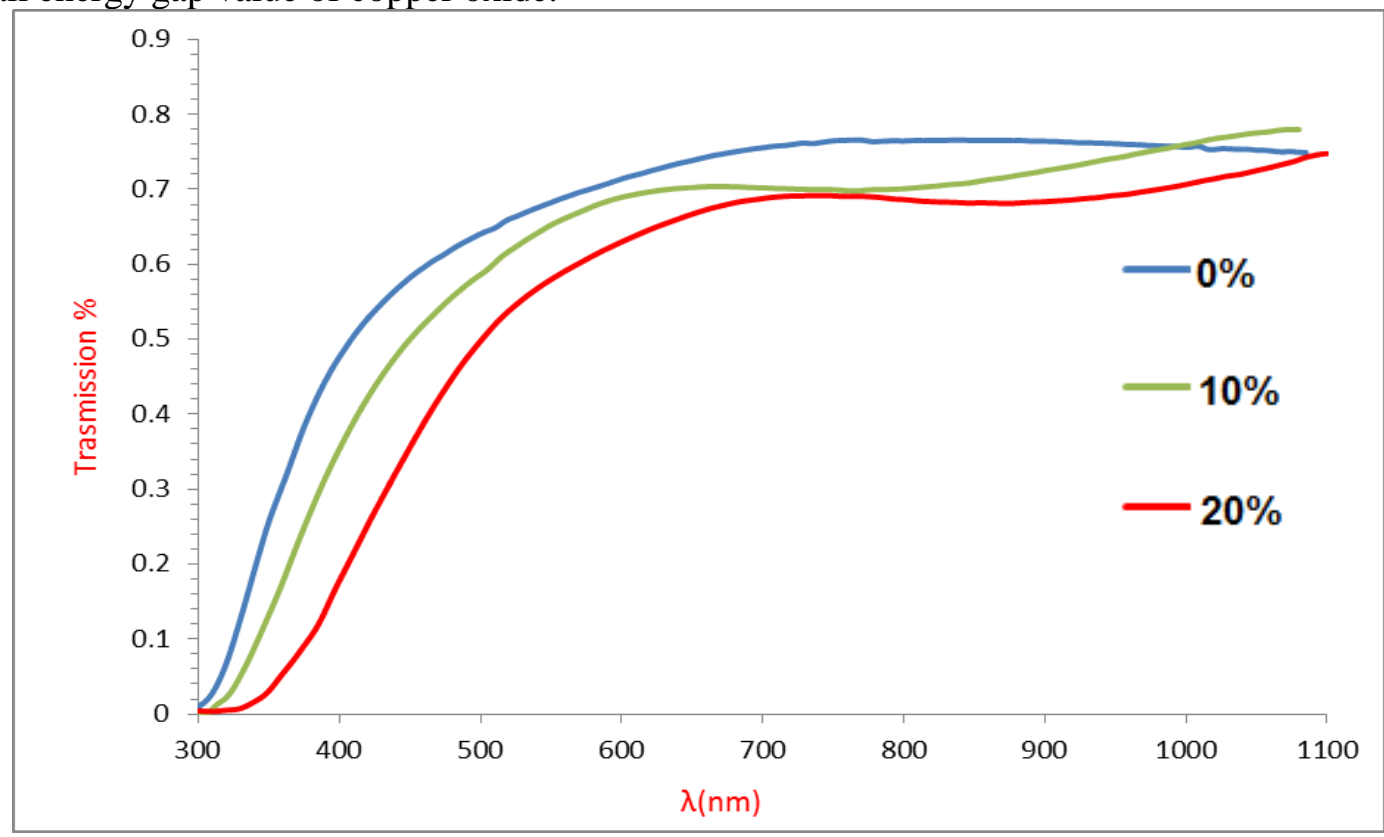

Figure 3-The transmittance spectrum values of $\operatorname{In}_{2} \mathrm{O}_{3}: \mathrm{CuO}$ thin films deposited on glass substrate . 


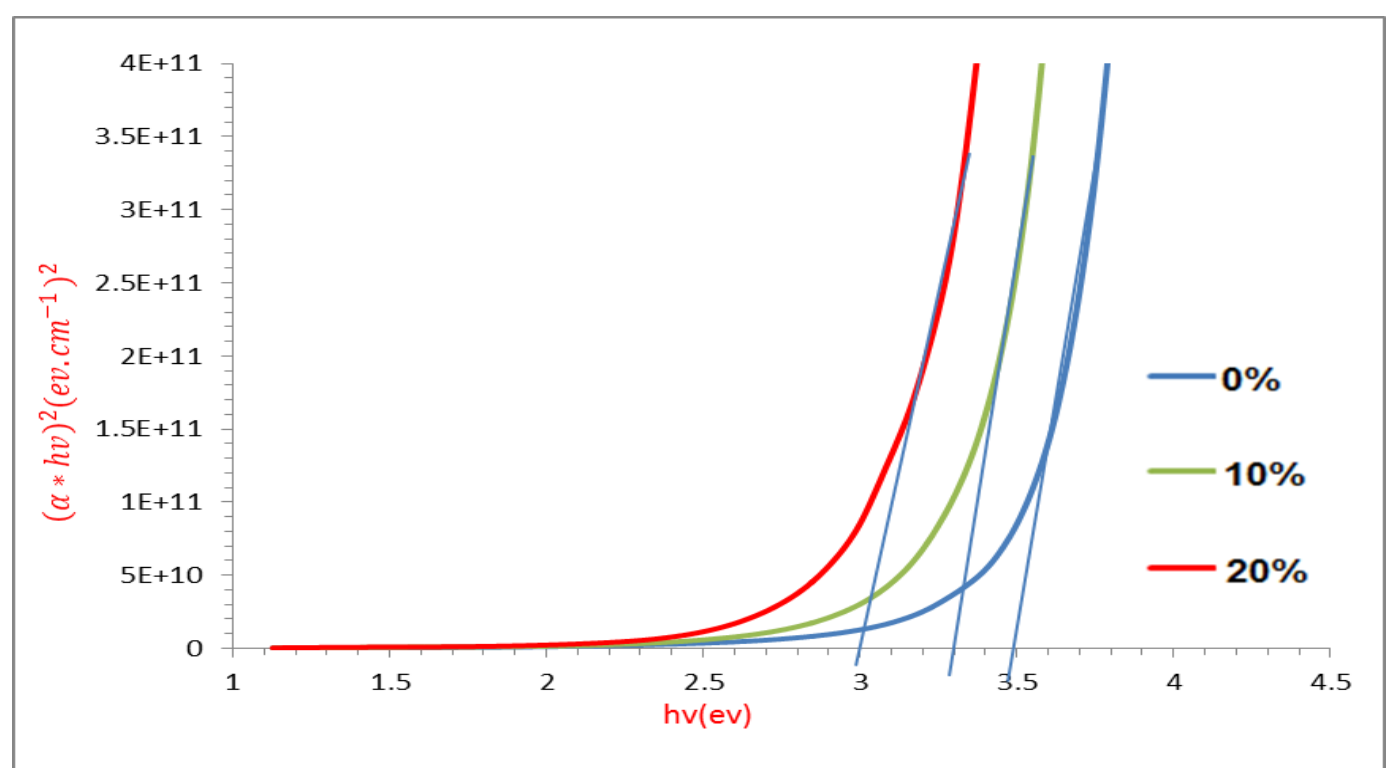

Figure 4-The energy gap values of $\operatorname{In}_{2} \mathrm{O}_{3}$ : $\mathrm{CuO}$ thin films deposited on glass substrate.

\section{3-3. Gas sensor characteristics}

The sensitivity of individual indium oxide and that mixed with copper oxide films toward $71 \mathrm{ppm}$ of $\mathrm{NH}_{3}$ gas was calculated through the following relationship [7]:

$$
S \%=\frac{R_{a}-R_{g}}{R_{a}} \times 100 \%
$$

where $\mathrm{Ra}$ and $\mathrm{Rg}$ are the electrical resistance values of the sensor in air and gas, respectively. Figures$(5,6,7)$ show the change in the electrical resistance of the sensor with the gas reaction time at different temperatures. Figure-5 shows the change in the electrical resistance verses time of indium oxide sensor towards NH3. Ammonia gas is one of the reducing gases, while indium oxide is considered an n-type semiconductor. Exposing this sensor to ammonia gas leads to a decrease in the electrical resistance value for the sensor from which the sensitivity was calculated, and its value was $(4.92 \%)$, while the response time was $12 \mathrm{~s}$ and the recovery time was $14 \mathrm{~s}$ at an operating temperature of $100^{\circ} \mathrm{C}$. Also, there was no response to the sensor at room temperature and when the operating temperature was increased to $250^{\circ} \mathrm{C}$. The sensitivity was equal to $5.47 \%$ while the response time was equal to $4 \mathrm{~s}$ and the recovery time was equal to $10 \mathrm{~s}$. When mixing a proportion of $10 \%$ copper solution, the sensitivity reached $8.81 \%$ ), the response time was $20 \mathrm{~s}$ and the recovery time was $11 \mathrm{~s}$ at an operating temperature of $200{ }^{\circ} \mathrm{C}$. By observing the results, it is concluded that the sensor is thermally activated, as the reaction between the surface of the sensor and ammonia gas increases with increasing temperature. The mixing ratio of $20 \%$ of the copper solution clearly led to an improvement in the sensitivity of the sensor, the response time, and the recovery time. The sensitivity of the sensor at $20 \%$ of copper solution reached $15.18 \%$, with a response time of $20 \mathrm{~s}$ and a recovery time $\mathrm{f} 8 \mathrm{~s}$, at an operating temperature of $100^{\circ} \mathrm{C}$. When the operating temperature was increased to $200^{\circ} \mathrm{C}$, the sensitivity increased to $75.06 \%$, while the response time was $10 \mathrm{~s}$ and recovery time was $11 \mathrm{~s}$, as shown in Table-2. 


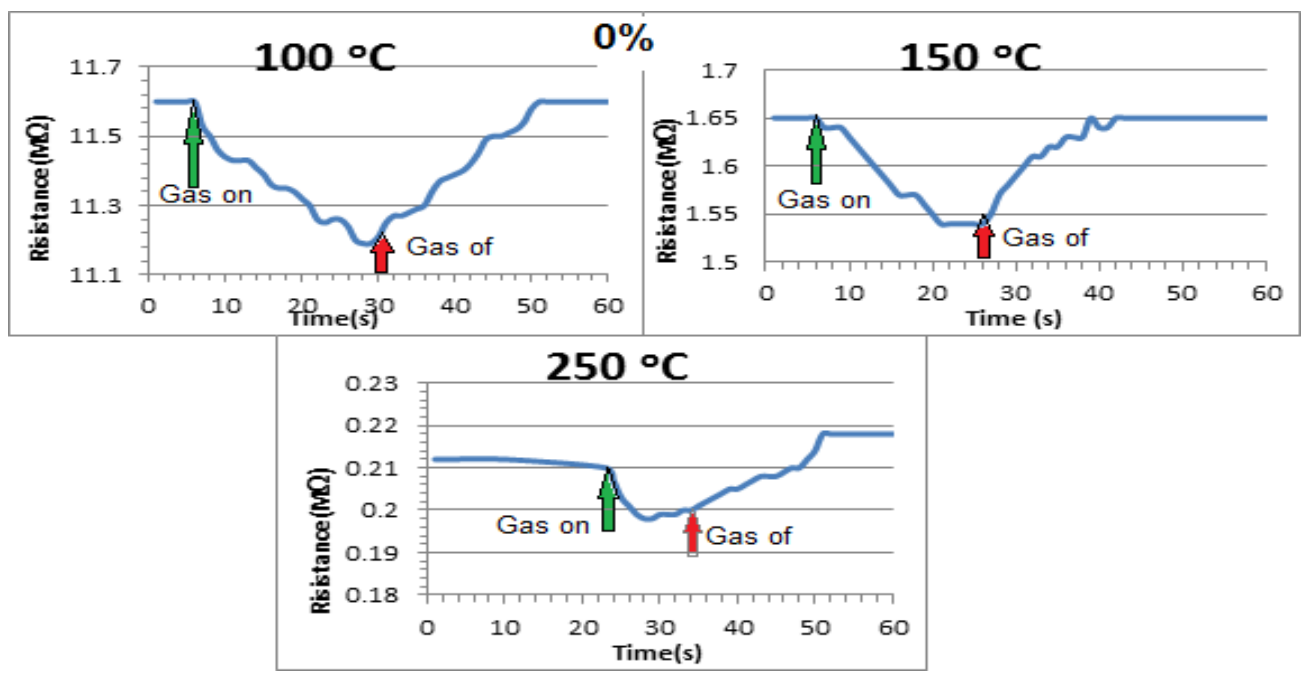

Figure 5-The change in electrical resistance with time for indium oxide films deposited on glass towards $\mathrm{NH}_{3}$ gas at a concentration of $71 \mathrm{ppm}$.
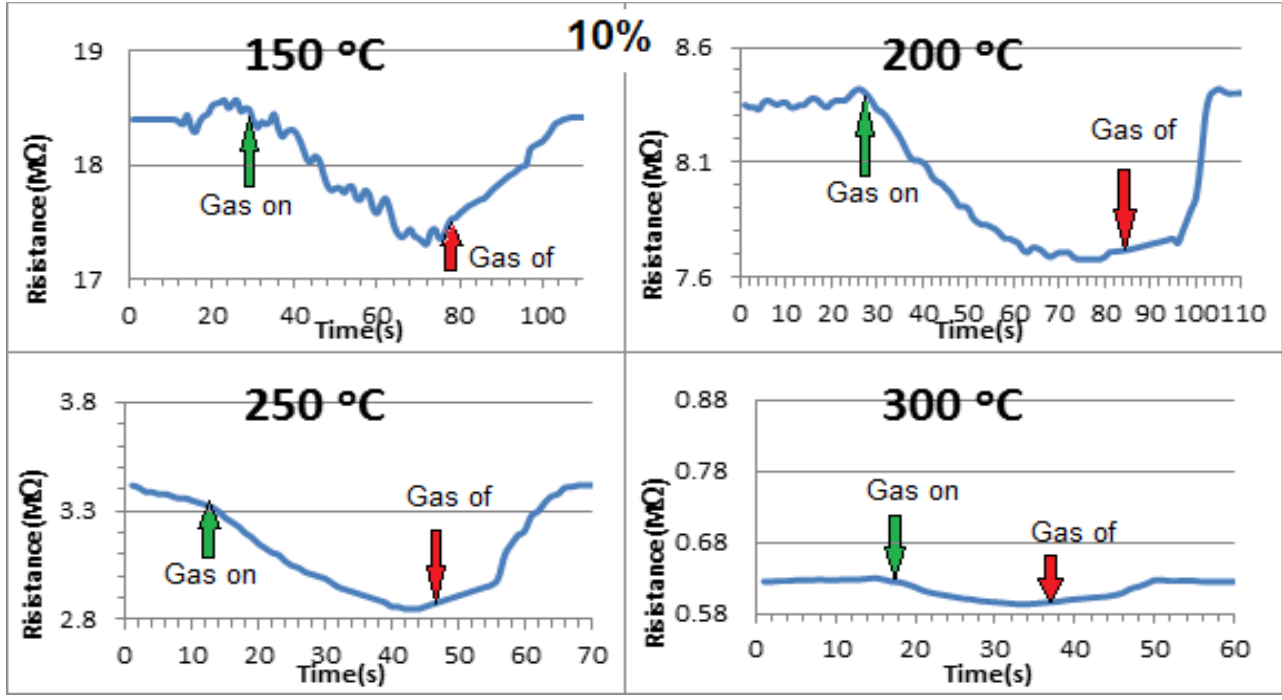

Figure 6-The change in electrical resistance with time for $90 \% \operatorname{~nn}_{2} \mathrm{O}_{3}: 10 \% \mathrm{CuO}$ mixture deposited on glass towards $\mathrm{NH}_{3}$ gas at a concentration of $71 \mathrm{ppm}$.

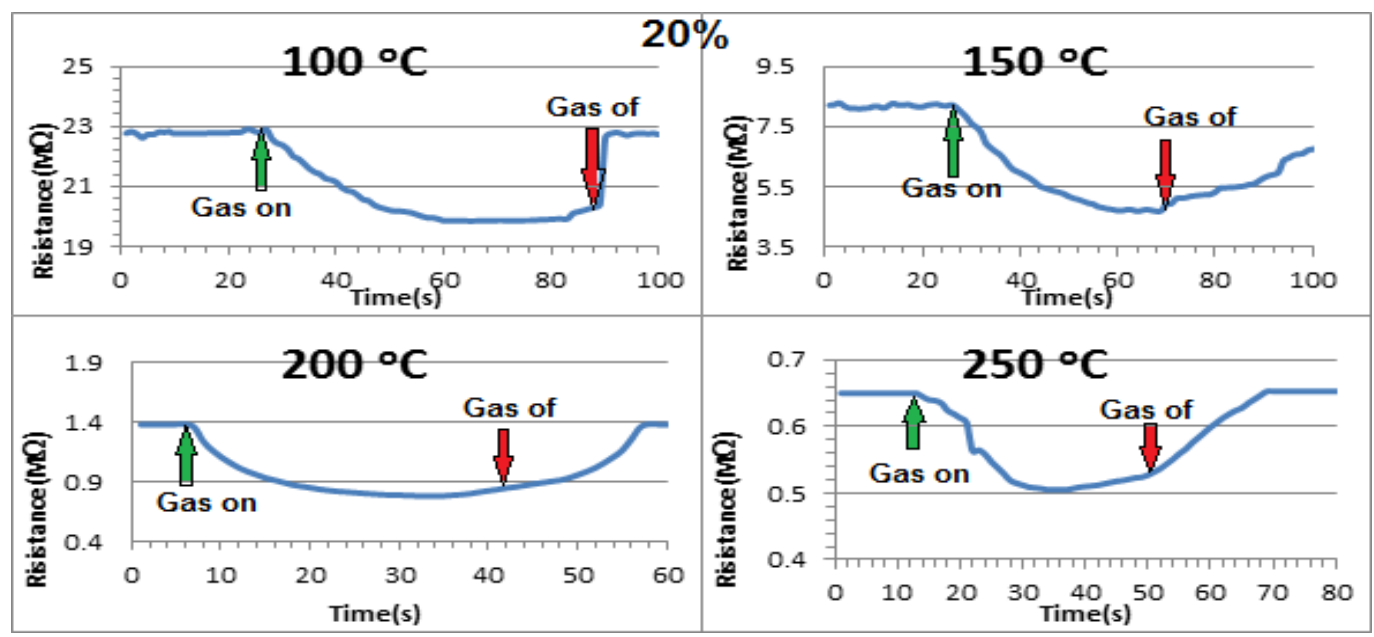

Figure 7-The change in electrical resistance with time for $80 \% \operatorname{In}_{2} \mathrm{O}_{3}: 20 \% \mathrm{CuO}$ thin films deposited on glass towards $\mathrm{NH}_{3}$ gas at a concentration of $71 \mathrm{ppm}$. 
Table 2-The values of the sensitivity, the response time, and the recovery time for the mixture of $\mathrm{In}_{2} \mathrm{O}_{3}-\mathrm{CuO}$ films deposited on glass toward $\mathrm{NH}_{3}$ gas at a concentration of $71 \mathrm{ppm}$.

\begin{tabular}{|c|c|c|c|c|c|}
\hline $\mathrm{CuCl}_{3} \%$ & Sample & $\begin{array}{l}\text { Operating } \\
\text { Tem. } C^{0}\end{array}$ & Sensitivity \% & $\begin{array}{l}\text { Response } \\
\text { Time (sec) }\end{array}$ & $\begin{array}{l}\text { Recovery Time } \\
(\mathrm{sec})\end{array}$ \\
\hline \multirow{3}{*}{0} & \multirow{3}{*}{$\mathrm{In}_{2} \mathrm{O}_{3}$} & 100 & 4.92 & 12 & 14 \\
\hline & & 150 & 6.62 & 10 & 12 \\
\hline & & 250 & 5.47 & 4 & 10 \\
\hline \multirow{4}{*}{10} & \multirow{4}{*}{$\mathrm{CuO}+\mathrm{In}_{2} \mathrm{O}_{3}$} & 150 & 6.55 & 28 & 16 \\
\hline & & 200 & 8.81 & 20 & 11 \\
\hline & & 250 & 13.22 & 16 & 10 \\
\hline & & 300 & 6.07 & 12 & 6 \\
\hline \multirow{4}{*}{20} & \multirow{4}{*}{$\mathrm{CuO}+\mathrm{In}_{2} \mathrm{O}_{3}$} & 100 & 15.18 & 20 & 8 \\
\hline & & 150 & 72.95 & 16 & 12 \\
\hline & & 200 & 75.06 & 10 & 11 \\
\hline & & 250 & 10.69 & 9 & 8 \\
\hline
\end{tabular}

Figure-8 shows the sensitivity change of the prepared films at different operating temperatures. From the observation of the figure we conclude that the optimal sensitivity of the prepared films to $\mathrm{NH}_{3}$ gas was at the mixing ratio of $20 \%$ of copper oxide. The reason is the contact p-n heterojunction between $\mathrm{CuO}$ and $\operatorname{In}_{2} \mathrm{O}_{3}$. Also from Figure-8, it is observed that the optimum operating temperature was decreased from $200{ }^{\circ} \mathrm{C}$ for $0 \%$ and $10 \%$ to $180{ }^{\circ} \mathrm{C}$ for $20 \%$ mixing ration. This means that the optimum mixing percentage between oxides is $20 \%$, which led to improving the sensitivity properties of the thin film.

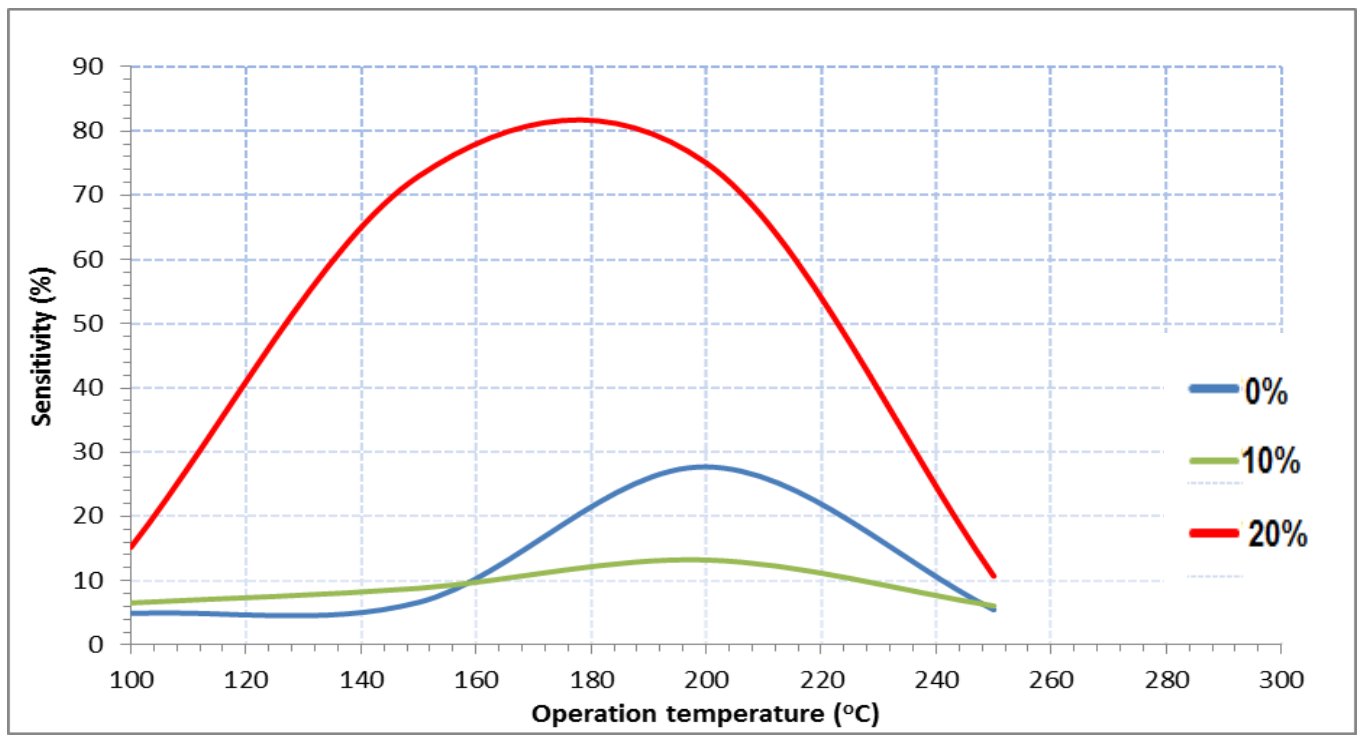

Figure 8- The sensitivity change with the change in the operating temperature of the $\operatorname{In}_{2} \mathrm{O}_{3}-\mathrm{CuO}$ thin films

The sensitization mechanism for most of the semiconducting metal oxides works on the principle of changing the conductivity of the sensor materials due to the interaction between the gas and the oxygen ions adsorbed on the surface $\left(\mathrm{O}_{2}, \mathrm{O}^{-}, \mathrm{O}^{2-}\right)$, which appears when the sensor is exposed to atmospheric oxygen. This leads to the formation of an area of depletion as a result of extracting electrons from the conduction band, thus increasing the barrier of sensor and thereby increasing the sensor resistance [18]. When the sensor is exposed to ammonia gas $\left(\mathrm{NH}_{3}\right)$, the gas reacts with oxygen ions and the electrons are released to the conduction band, which leads to a decrease in the electrical resistance of the sensor, according to the following equations [19]:

$$
\begin{aligned}
& 4 \mathrm{NH}_{3}+3 \mathrm{O}_{2(\mathrm{ads})}^{-}---\rightarrow 2 \mathrm{~N}_{2}+6 \mathrm{H}_{2} \mathrm{O}+6 \mathrm{e}^{-} \\
& 2 \mathrm{NH}_{3(\mathrm{ads})}+3 \mathrm{O}_{(\mathrm{ads})}^{-}--\rightarrow \mathrm{N}_{2}+3 \mathrm{H}_{2} \mathrm{O}+3 \mathrm{e}^{-}
\end{aligned}
$$


This reaction requires activation energy, which means that it requires the provision of heat. For this reason, the $\operatorname{In}_{2} \mathrm{O}_{3}-\mathrm{CuO}$ mixture sensor does not obtain a response at room temperature or at lower temperatures, while the response is as high as possible when the actual thermal energy $\left(100^{\circ} \mathrm{C}\right)$ is given for the reaction, reaching to the optimum temperature. Also, we note that above this temperature, the response was decreased, due to the desorbed of oxygen ions from the surface of the sensor [7, 20-22].

\section{Conclusions}

The sensor was prepared at $400^{\circ} \mathrm{C}$ from depositing indium oxide-copper oxide mixture nanocomposites film by using the chemical spray pyrolysis method. The XRD and AFM analyses were used to study the structural properties, which indicated that the prepared films are polycrystalline. They had grain size that was decreased with increasing the copper mixing ratio, while the surface roughness was increased. The optical properties were examined by using UV-Visible spectrometer and the results showed that the transmittance decreases with increasing the mixing ratio of the copper solution. The direct optical energy gap ranged between 3.5 and $3 \mathrm{eV}$ and was decreased with increasing the mixing ratio of the copper solution. The sensitivity of the prepared thin films was measured towards $\mathrm{NH}_{3}$ gas at a concentration of $71 \mathrm{ppm}$. The sensitivity of the mixture showed a higher value than that for individual indium oxide, with lower response time and recovery time. The optimum sensitivity value and the operating temperature were achieved at a $20 \%$ mixing ratio of copper oxide.

\section{Acknowledgement}

This research is supported by the scientific committee in the Physics Department, College of Education for Pure Sciences at the University of Anbar.

\section{References}

1. Kanan, Sofian M,El-Kadri, Oussama M,Abu-Yousef, Imad A,Kanan, Marsha C. 2009. Semiconducting metal oxide based sensors for selective gas pollutant detection. Sensors, 9(10): 8158-8196.

2. Liu, Chang,Gao, Hongyu,Wang, Liwei,Wang, Tianshuang,Yang, Xueli,Sun, Peng,Gao, Yuan,Liang, Xishuang,Liu, Fengmin,Song, Hongwei. 2017.Facile synthesis and the enhanced sensing properties of Pt-loaded $\alpha-\mathrm{Fe}_{2} \mathrm{O}_{3}$ porous nanospheres. Sensors and Actuators B: Chemical, 252: 1153-1162.

3. Yang, Shuqin,Song, Zhilong,Gao, Naibo,Hu, Zhixiang,Zhou, Licheng,Liu, Jingyao,Zhang, Baohui,Zhang, Guangzu,Jiang, Shenglin,Li, Hua-Yao. 2019. Near room temperature operable $\mathrm{H}_{2} \mathrm{~S}$ sensors based on $\mathrm{In}_{2} \mathrm{O}_{3}$ colloidal quantum dots. Sensors and Actuators B: Chemical, 286: 22-31.

4. Trakhtenberg, LI,Gerasimov, GN,Gromov, VF,Belysheva, TV,Ilegbusi,OJ. 2012. Effect of composition on sensing properties of $\mathrm{SnO}_{2}+\mathrm{In}_{2} \mathrm{O}_{3}$ mixed nanostructured films. Sensors and Actuators B: Chemical, 169: 32-38.

5. Suhail, Mahdi Hasan,Al-Jumily, Hamad Saleh,Abdullah, Omed Gh. 2019. Characterization and $\mathrm{NO}_{2}$ gas sensing performance of $\mathrm{CdO}: \operatorname{In}_{2} \mathrm{O}_{3}$ polycrystalline thin films prepared by spray pyrolysis technique. SN Applied Sciences, 1(1): 69.

6. Nayel, Hajar H,AL-Jumaili, Hamid S. 2019. Fabrication of Highly Sensitive NH3 Sensor Based on Mixed $\mathrm{In}_{2} \mathrm{O}_{3}-\mathrm{Ag}_{\mathrm{x}} \mathrm{O}$ Nanostructural Thin Films deposited on porous silicon. Journal of university of Anbar for Pure science, 13(2): 40-47.

7. Al-Jumaili, HS, Jasim, MN. 2019. Preparation And Characterization Of Zno: $\mathrm{Sno}_{2} \mathrm{Nanocomposite}$ Thin Films On Porous Silicon As $\mathrm{H}_{2} \mathrm{~S}$ Gas Sensor. Journal of Ovonic Research, 2(1): 81-87.

8. Suhail, Mahdi Hasan. 2017. Preparation and characterization of mixed $\mathrm{SnO}_{2}$ : $\mathrm{CdO}$ thin films as gas sensor. Iraqi Journal of Physics (IJP), 15(33): 28-39.

9. Li, Tian-tian,Bao, Na,Geng, Ai-fang,Yu, Hui,Yang, Ying,Dong, Xiang-ting. 2018. Study on room temperature gas-sensing performance of $\mathrm{CuO}$ film-decorated ordered porous $\mathrm{ZnO}$ composite by $\mathrm{In}_{2} \mathrm{O}_{3}$ sensitization. Royal Society open science, 5(2): 171788.

10. Ma, Zhi-Hong, Yu, Rui-Tao,Song, Ji-Ming. 2020. Facile synthesis of Pr-doped $\operatorname{In}_{2} \mathrm{O}_{3}$ nanoparticles and their high gas sensing performance for ethanol. Sensors and Actuators B: Chemical, 305: 127377. 
11. Bhuvaneshwari, S, Gopalakrishnan, N. 2016. Enhanced ammonia sensing characteristics of $\mathrm{Cr}$ doped $\mathrm{CuO}$ nanoboats. Journal of Alloys and Compounds, 654: 202-208.

12. Highly sensitive and selective gas sensors using p-type oxide semiconductors: Overview, Highly sensitive and selective gas sensors using p-type oxide semiconductors: Overview. Sensors and Actuators B: Chemical, 2014. 192: 607-627.

13. Srivastava, J., Gupta, Amit,Bhaskar, Anand A. 2014. Sensing behavior of CuO-doped $\mathrm{SnO}_{2}$ thick film sensor for $\mathrm{H}_{2} \mathrm{~S}$ detection. Int. J. Scientific and Technology Research, 3(5): 266-272.

14. Li,Ching-Feng,Hsu,Chia-Yen, $\mathrm{Li}$, Yuan-Yao. 2014. $\mathrm{NH}_{3}$ sensing properties of $\mathrm{ZnO}$ thin films prepared via sol-gel method. Journal of Alloys and Compounds, 606 : 27-31.

15. Yuasa, Masayoshi,Masaki, Takanori,Kida,Tetsuya,Shimanoe, Kengo,Yamazoe, Noboru. 2009. Nano-sized $\mathrm{PdO}$ loaded $\mathrm{SnO}_{2}$ nanoparticles by reverse micelle method for highly sensitive $\mathrm{CO}$ gas sensor. Sensors and Actuators B: Chemical,136(1): 99-104.

16. Wojtyła, Szymon,Baran, Tomasz. 2020. Electrochemically prepared copper/indium oxides photocathode for efficient photoelectrochemical hydrogen production. Solar Energy Materials and Solar Cells, 206: 110262.

17. Sofi, AH,Shah, MA. 2019. Structural and electrical properties of copper doped $\operatorname{In}_{2} \mathrm{O}_{3}$ nanostructures prepared by citrate gel processes. Materials Research Express, 6(4): 045039.

18. Kumar, Nagesh,Srivastava, AK,Nath, R,Gupta, Bipin Kumar,Varma, GD. 2014. Probing the highly efficient room temperature ammonia gas sensing properties of a luminescent $\mathrm{ZnO}$ nanowire array prepared via an AAO-assisted template route. Dalton Transactions, 43(15): 5713-5720.

19. Vinoth,E,Gopalakrishnan, N. 2018. Effect of temperature on $\mathrm{NH}_{3}$ sensing by $\mathrm{ZnO}: \mathrm{Mg}$ thin film grown by radio frequency magnetron sputtering technique. in AIP Conference Proceedings. AIP Publishing LLC.

20. Jasim, Ismaail K,Ibrahim, Isam $\mathrm{M}$,Alyas, Marwan K. 2018. $\operatorname{In}_{2} \mathrm{O}_{3}-\mathrm{ZnO}$ pyramids like structure prepared by Spray-pyrolysis Technique for gas Sensing Applications. Iraqi Journal of Science, 6774.

21. Zheng, Zhao Qiang,Zhu, Lian Feng,Wang,Bing. 2015. $\mathrm{In}_{2} \mathrm{O}_{3}$ nanotower hydrogen gas sensors based on both schottky junction and thermoelectronic emission. Nanoscale Research Letters, 10(1): 293.

22. Nayel, Hajar H,AL-Jumaili, Hamid S. 2020. Synthesis and characterization of silver oxide nanoparticles prepared by chemical bath deposition for $\mathrm{NH}_{3}$ gas sensing applications. Iraqi Journal of Science, 61(4): 772-779. 